\title{
A Research of Peripheral Blood Cells Annually in Bufo Bufo gargarizans
}

\author{
Investigación de las Células Sanguíneas Periféricas \\ en un Periodo Anual del Bufo Bufo gargarizans
}

Chongbin Liu*; Chengqiang Xia ${ }^{* *}$; Zhaohui Xie**; Yang Jiao** \& Qiusheng She**

LIU, C.; XIA, C.; XIE, Z.; JIAO, Y. \& SHE, Q. A Research of peripheral blood cells annually in Bufo Bufo gargarizans. Int. J. Morphol., 31(4):1282-1288, 2013.

SUMMARY: The present paper deals with a histological study of the blood cells of Bufo Bufo gargarizans in different months: January, March, May, July and October. The methods used are by routine blood smear in Wright stain and observation in vivo. We found that in smears and in vivo two main types of cells of the red cells: mitotic as well as amitotic. While amitotic occurs all the year round, particularly in July, mitosis so far had been seen only in July. It is also found that there are plenty of neutrophils in the blood cells of Bufo Bufo gargarizans, furthermore, the nuclei of these cells are polymorphic, especially in January and March. Meanwhile, the concentration of red cells was lowest in May and highest in January; The concentration of white blood cells was highest in October and lowest in March; As to granulocytes, eosinophils in July and October had higher proportion, while neutrophils and basophils in July; in agranulocytes, mononuclear cells reached the highest value in March, lowest in January, lymphocytes and the maximum value appeared in May, the lowest value appeared in July. Morphological changes of thrombocytes were not obvious.

KEY WORDS: Bufo Bufo gargarizans; Blood cells; Annual changes.

\section{INTRODUCTION}

Bufo Bufo gargarizans are mainly distributed in most areas of China, and are commonly found in damp grass and soil holes below the altitude of $1500 \mathrm{~m}$. Blood cells are important components of animal blood, playing an important role in gas transport immunity and blood coagulation. The morphology and number of blood cells are important indexes of animal physiological status as well as disease diagnosis, meanwhile, morphological characteristics of blood cells have a certain relationship with animal classification and system evolution, hence, the study of animal blood cells has attracted a lot of attention. There has been some research on blood cells in Bufo Bufo gargarizans at home and abroad (Guo et al., 2002; Zhou et al., 2001; Li et al., 2009; Hou et al., 1995; Pan et al., 1956), but observations and analysis on annual period of blood cells have not been reported. Therefore, through the observation of annual period of blood cells in Bufo Bufo gargarizans, the paper aims to provide data on diversity for the study of annual changes of blood cells in amphibians and provide morphological data for studying adaptation mechanism of blood cells in hibernation.

\section{MATERIAL AND METHOD}

Sources of Materials. Collect healthy adults of Bufo Bufo gargarizans, totally five times: respectively in January, March, May, July and October in 2012, with the single collecting number of no less than 15 . Totally 95 Bufo Bufo gargarizans have been collected (female 21, male 74), and the gathering place is Bai Guishan Reservoir Wetland, Ping Dingshan city.

Sample Preparation and Observation. Samples are processed in $24 \mathrm{~h}$ after being collected. Samples were anesthetized with ethyl ether before blood-drawing processing, open pericardial cavity when samples are in a coma, peripheral blood was drawn from aortic stem with a needle tube, and anticoagulate with ACD liquid. Blood smears were treated with conventional methods with Wright's staining, observed by Nikon microscope and photographed. Then 300 red blood cells were immediately selected, and 100 cells of other types were selected, measuring the size of the cells by Image-Pro Plus software. Blood used for redcell counting was diluted with ringer solution, blood used for white-cell counting was diluted with acetic acid gentian

\footnotetext{
* Department of Physiology, HuZhou Normal College, HuZhou 313000, Zhejiang province, People's Republic of China.

** Department of Bioengineering, Henan University of Urban Construction, Pingdingshan, Henan province, People's Republic of China.
} 
violet liquid, statistical analysis was subsequently carried out in the Neubauer counting plate under the microscope.

\section{RESULTS}

Blood cells of Bufo Bufo gargarizan include red blood cells (RBC), white blood cells (WBC) as well as thrombocyte (TBC), and the measurement results of morphological parameters are shown in Tables I, II and III.

Red Blood Cells. Morphology of red blood cells in Bufo Bufo gargarizans are diverse, including oval-shaped mature red blood cells (Fig. 1.1), immature red blood cells (Fig. 1.1), suborbicular juvenile red cells (Fig. 1.2), we can see the red blood cells in division stage (Fig. 1.3), and spindleshaped red blood cells (Fig. 1.1), pear-shaped red blood cells (Fig. 1.4), and the development of non-nucleated red blood cells (Fig. 1.5) also can be seen after amitosis. Meanwhile, part of red blood cells present the form of the pseudopod or the transformation ( Fig. 1.6). In the observation of blood smears of Bufo Bufo gargarizans in each month, the "shadow" red blood cells which are stained pink or lilac color can be observed ( Fig. 1.7).

The minimum major diameter of mature red cells (MRBC) appears in May and July, while the maximum appears in January, hence the difference between major diameter of mature red cells in January and October and that in other months is extremely significant. The ratio of major diameter to minor axis in mature red blood cells reaches its minimum in July and October while reaches its maximum in March. The minimum value of major diameter in cell nuclei of mature red cells appears in May and the maximum value appears in
October, besides, the ratio of nuclear major diameter to nuclear minor axis changes little.

Cell bodies and nuclei of immature red blood cells (IRBC) are round or oval.

White Blood Cells. White blood cells of Bufo Bufo gargarizans are divided into granulocytes and agranulocytes: the former includes mononuclear cells (MNC) and lymphocytes (LPC); because the latter have significant granules, hence according to granules' different selectivity to dyestuff, agranulocytes can fall into three categories: neutrophils (NP), eosinophils (EP) and basophils. Differential counting of white blood cells lies in Figure 2.

Granulocytes. Neutrophils (NP) account for $21.31 \%$ of white blood cells, and $57.22 \%$ in granulocytes. The cells are round or oval, and nucleo-cytoplasmic boundary is obvious. Nucei are divided into monolobate nucei and multilobate nucei: monolobate nucei have bacillary shape (Fig. 1.8), oval shape (Fig. 1.9), kidney shape (Fig. 1.9), dumbbell shape (Fig. 1.10), etc. multilobate nucei are divided into bilobate nucei (Fig. 1.11), trilobate nucei (Fig. 1.12) or nucei with more lobes (Fig. 1.13.) Lobes are connected by linins, but there have been very few with no linin connected (Fig. 1.14). Nucei are stained bluish violet, and cytoplasms contains many neutrophils stained bluish violet. Compared with neutrophils in other months, polymorphonuclear neutrophils account for largest proportion of neutrophils.

Eosinophils (EP) account for $7.61 \%$ in white cells and $20.44 \%$ in the granulocytes. Eosinophils are round or oval, and the volume of mature bodies is relatively large. The nuclei are rough, stained purple, oval, and located in the center (Fig. 1.15) or on the side of the cell (Fig. 1.16), The nuclei are also

Table I. Morphological parameters of RBC of Bufo Bufo gargarizan.

\begin{tabular}{cccccccc}
\hline & Parameters & January & March & May & July & October & FA test \\
\hline \multirow{4}{*}{ MRBC } & LA $(\mu \mathrm{m})$ & $21.49 \pm 1.63$ & $20.27 \pm 1.52$ & $19.91 \pm 1.58$ & $19.91 \pm 1.88$ & $21.35 \pm 1.76$ & $>\mathrm{F} 0.01$ \\
& SA $(\mu \mathrm{m})$ & $14.91 \pm 1.27$ & $13.87 \pm 1.34$ & $14.24 \pm 1.27$ & $14.43 \pm 1.50$ & $15.47 \pm 1.22$ & $<\mathrm{F} 0.01$ \\
& SA:LA & 1.44 & 1.46 & 1.4 & 1.38 & 1.38 & $<\mathrm{F} 0.01$ \\
& NLA $(\mu \mathrm{m})$ & $8.71 \pm 1.05$ & $9.11 \pm 1.06$ & $8.29 \pm 1.13$ & $9.68 \pm 1.11$ & $10.69 \pm 1.45$ & $<\mathrm{F} 0.01$ \\
& NSA $(\mu \mathrm{m})$ & $5.83 \pm 0.77$ & $5.77 \pm 0.85$ & $5.43 \pm 0.76$ & $6.5 \pm 0.96$ & $6.08 \pm 0.93$ & $>\mathrm{F} 0.01$ \\
& NLA:NSA & 1.49 & 1.58 & 1.53 & 1.49 & 1.66 & $<\mathrm{F} 0.01$ \\
& LA $(\mu \mathrm{m})$ & $15.05 \pm 1.47$ & $15.25 \pm 1.65$ & $14.56 \pm 1.05$ & $14.29 \pm 1.80$ & $14.61 \pm 1.58$ & $>\mathrm{F} 0.01$ \\
& SA $(\mu \mathrm{m})$ & $12.44 \pm 1.64$ & $12.09 \pm 1.59$ & $11.89 \pm 1.45$ & $11.75 \pm 1.40$ & $12.5 \pm 1.64$ & $>\mathrm{F} 0.01$ \\
& SA: LA & 1.21 & 1.26 & 1.22 & 1.22 & 1.17 & $>\mathrm{F} 0.01$ \\
& NLA $(\mu \mathrm{m})$ & $7.27 \pm 1.07$ & $7.01 \pm 0.92$ & $7.28 \pm 0.72$ & $7.32 \pm 0.89$ & $7.64 \pm 1.10$ & $>\mathrm{F} 0.01$ \\
& $\mathrm{NSA}(\mu \mathrm{m})$ & $5.36 \pm 0.93$ & $5.21 \pm 0.82$ & $5.81 \pm 0.78$ & $5.19 \pm 0.84$ & $5.69 \pm 0.99$ & $>\mathrm{F} 0.01$ \\
& $\mathrm{NLA}: \mathrm{NSA}$ & 1.36 & 1.35 & 1.25 & 1.41 & 1.34 & $<\mathrm{F} 0.01$ \\
\hline
\end{tabular}

$\mathrm{LA}=$ long axis; $\mathrm{SA}=$ short axis; $\mathrm{NLA}=$ long axis of nuclei; $\mathrm{NSA}=$ short axis of nuclei. 
Table II. Morphological parameters of WBC of Bufo Bufo gargarizan.

\begin{tabular}{|c|c|c|c|c|c|c|c|}
\hline & Parameters & January & March & May & July & October & FA test \\
\hline \multirow{3}{*}{ NP } & $\mathrm{LD}(\mu \mathrm{m})$ & $16.19 \pm 1.95$ & $16.98 \pm 2.12$ & $17.12 \pm 2.16$ & $16.75 \pm 1.88$ & $17.37 \pm 1.84$ & $>\mathrm{F} 0.01$ \\
\hline & $\mathrm{SD}(\mu \mathrm{m})$ & $13.24 \pm 1.81$ & $14.12 \pm 1.96$ & $13.93 \pm 2.07$ & $13.67 \pm 1.57$ & $13.43 \pm 1.37$ & $>\mathrm{F} 0.01$ \\
\hline & $\mathrm{CF}(\mu \mathrm{m})$ & $50.18 \pm 6.61$ & $52.79 \pm 5.85$ & $52.78 \pm 7.29$ & $53.13 \pm 5.72$ & $54.13 \pm 4.91$ & $>\mathrm{F} 0.01$ \\
\hline \multirow{3}{*}{ EP } & $\mathrm{SD}(\mu \mathrm{m})$ & $14.09 \pm 2.14$ & $15.04 \pm 1.83$ & $15.37 \pm 1.94$ & $15.56 \pm 2.08$ & $13.86 \pm 1.13$ & $>\mathrm{F} 0.01$ \\
\hline & $\mathrm{LD}(\mu \mathrm{m})$ & $12.25 \pm 1.92$ & $13.67 \pm 1.67$ & $13.78 \pm 1.67$ & $13.96 \pm 1.93$ & $12.58 \pm 1.26$ & $>\mathrm{F} 0.01$ \\
\hline & $\mathrm{CF}^{\mathrm{a}}(\mu \mathrm{m})$ & $43.91 \pm 6.92$ & $47.33 \pm 7.05$ & $47.33 \pm 7.05$ & $50.18 \pm 6.82$ & $44.41 \pm 3.95$ & $>\mathrm{F} 0.01$ \\
\hline \multirow{3}{*}{$\mathrm{BP}$} & $\mathrm{LD}(\mu \mathrm{m})$ & $11.65 \pm 1.50$ & $12.84 \pm 1.70$ & $11.70 \pm 1.36$ & $11.24 \pm 1.23$ & $11.51 \pm 1.50$ & $>\mathrm{F} 0.01$ \\
\hline & $\mathrm{SD}(\mu \mathrm{m})$ & $10.28 \pm 1.46$ & $11.33 \pm 1.63$ & $10.44 \pm 1.37$ & $10.01 \pm 1.06$ & $10.25 \pm 1.28$ & $>\mathrm{F} 0.01$ \\
\hline & $\mathrm{CF}(\mu \mathrm{m})$ & $36.53 \pm 4.92$ & $40.96 \pm 5.21$ & $36.41 \pm 4.22$ & $35.61 \pm 2.91$ & $35.83 \pm 4.45$ & $<\mathrm{F} 0.01$ \\
\hline \multirow{3}{*}{$\mathrm{MNC}$} & $\mathrm{LD}(\mu \mathrm{m})$ & $15.04 \pm 2.35$ & $15.65 \pm 1.75$ & $15.91 \pm 2.31$ & $16.26 \pm 2.54$ & $16.81 \pm 2.77$ & $>\mathrm{F} 0.01$ \\
\hline & $\mathrm{SD}(\mu \mathrm{m})$ & $13.27 \pm 2.26$ & $13.78 \pm 1.50$ & $13.84 \pm 1.59$ & $13.59 \pm 1.39$ & $11.76 \pm 0.98$ & $>\mathrm{F} 0.01$ \\
\hline & $\mathrm{CF}(\mu \mathrm{m})$ & $47.46 \pm 7.45$ & $49.69 \pm 5.77$ & $50.15 \pm 6.98$ & $51.79 \pm 7.73$ & $49.94 \pm 8.05$ & $>\mathrm{F} 0.01$ \\
\hline \multirow{3}{*}{ SLPC } & $\mathrm{LD}(\mu \mathrm{m})$ & $13.17 \pm 1.07$ & $13.16 \pm 1.06$ & $13.77 \pm 1.37$ & $13.31 \pm 1.11$ & $13.48 \pm 0.82$ & $>\mathrm{F} 0.01$ \\
\hline & $\mathrm{SD}(\mu \mathrm{m})$ & $11.51 \pm 1.26$ & $11.48 \pm 1.31$ & $12.19 \pm 1.42$ & $11.68 \pm 1.04$ & $12.10 \pm 1.31$ & $>\mathrm{F} 0.01$ \\
\hline & $\mathrm{CF}(\mu \mathrm{m})$ & $41.84 \pm 4.13$ & $41.22 \pm 3.87$ & $43.49 \pm 4.52$ & $43.55 \pm 5.25$ & $42.45 \pm 4.25$ & $>\mathrm{F} 0.01$ \\
\hline \multirow{3}{*}{ LLPC } & $\mathrm{LD}(\mu \mathrm{m})$ & $8.57 \pm 1.11$ & $9.00 \pm 1.22$ & $8.72 \pm 1.29$ & $9.29 \pm 1.22$ & $8.67 \pm 1.31$ & $>\mathrm{F} 0.01$ \\
\hline & $\mathrm{SD}(\mu \mathrm{m})$ & $7.62 \pm 1.01$ & $7.93 \pm 1.28$ & $7.88 \pm 1.16$ & $8.22 \pm 1.20$ & $7.56 \pm 1.10$ & $>\mathrm{F} 0.01$ \\
\hline & $\mathrm{CF}(\mu \mathrm{m})$ & $26.68 \pm 3.73$ & $28.50 \pm 4.14$ & $28.17 \pm 4.14$ & $30.46 \pm 4.36$ & $27.59 \pm 3.75$ & $>\mathrm{F} 0.01$ \\
\hline
\end{tabular}

$\mathrm{CF}=$ circumference; the others are the same as $\mathrm{T} 1$.

Table III. Morphological parameters of TBC of Bufo Bufo gargarizan.

\begin{tabular}{lcccccc}
\hline & January & March & May & July & October & FA test $^{\mathbf{a}}$ \\
\hline LD $(\mu \mathrm{m})$ & $14.64 \pm 1.99$ & $14.70 \pm 2.03$ & $11.88 \pm 1.30$ & $12.39 \pm 1.66$ & $13.32 \pm 1.68$ & $>\mathrm{F}_{0.01}$ \\
SD $(\mu \mathrm{m})$ & $6.28 \pm 1.16$ & $7.06 \pm 0.89$ & $6.19 \pm 0.96$ & $5.56 \pm 1.12$ & $5.96 \pm 0.78$ & $>\mathrm{F}_{0.01}$ \\
LD:SD & 2.33 & 2.08 & 1.92 & 2.23 & 2.23 & $<\mathrm{F}_{0.01}$ \\
\hline
\end{tabular}

divided into bilobate nuclei (Fig. 1.17) and multilobate nuclei (Fig. 1.18); The cytoplasms are filled with orange eosinophil granules, and granules are large with varying numbers. Cytoplasms are annular with the edges stained deeply while the center stained lightly.

Basophils (BP) takes $8.32 \%$ of white cells and $22.34 \%$ in granulocytes. The cells are orbicular or suborbicular (Fig. 1.19), and the size is smaller than eosinophilic cells. The nuclei of basophils are often excentric. The cytoplasms contain basophilic granules stained bluish violet. The sizes of granules are uneven, and they are often covering the surface of the nuclei.

The morphology of three kinds of granular leukocytes changes through the whole year, and eosinophils change most, followed by basophils, and then neutrophils. The major diameter of eosinophils reaches the maximum value in July and the minimum value in October, and it can be seen from the charts that there are significant differences in morphology between eosinophils in July and those in January and October; the major diameter of basophils reaches the maximum value in March and the minimum value in July. Differences between basophils in March and those in other months are extremely significant; the major diameter of neutrophils is maximized in October and minimized in January.

Agranulocytes. Agranulocytes include monocytes (MNC) and lymphocytes (LPC). Monocytes account for $5.36 \%$ in white blood cells. The cells are oval (Fig. 1.20), dumbbell-shaped (Fig. 1.21), U-shaped (Fig. 1.22), etc. Nuclei are large and often excentric, but some nuclei are located in the center (Fig. 1.20). Nuclei are stained violet red, and cytoplasms are gray blue. Cytoplasms are in translucent state with cytoplasmic processes. The major diameter of monocytes increases gradually from January to October and reaches the maximum value in October. Agranulocytes account for $6.95 \%$ of nongranular leukocytes. 

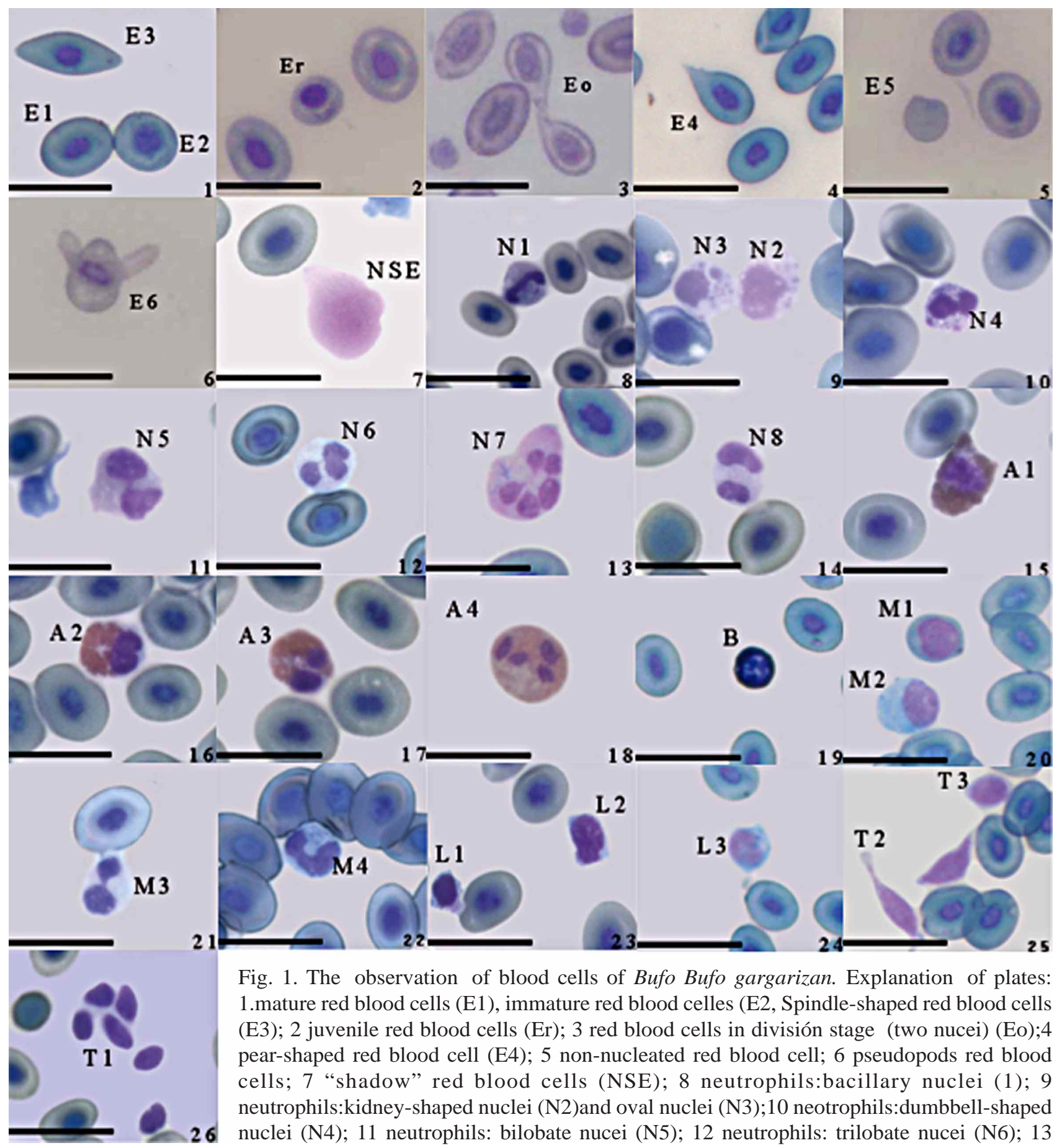

Fig. 1. The observation of blood cells of Bufo Bufo gargarizan. Explanation of plates: 1.mature red blood cells (E1), immature red blood celles (E2, Spindle-shaped red blood cells (E3); 2 juvenile red blood cells (Er); 3 red blood cells in división stage (two nucei) (Eo);4 pear-shaped red blood cell (E4); 5 non-nucleated red blood cell; 6 pseudopods red blood cells; 7 "shadow" red blood cells (NSE); 8 neutrophils:bacillary nuclei (1); 9 neutrophils:kidney-shaped nuclei (N2)and oval nuclei (N3);10 neotrophils:dumbbell-shaped nuclei (N4); 11 neutrophils: bilobate nucei (N5); 12 neutrophils: trilobate nucei (N6); 13 neutrophils: multilobate nucei (N7); 14 neutrophils: bilobate nucei (no linin)(N8);15 eosinophils: nuclei located in the center of the cells (A1); 16 eosinophils: nuclei located on one side of the cells (A2);17 eosinophils: bilobate nucei (A3); 18 eosinophils: multilobate nucei(M3); 22 mononuclear cells: U-shape nuclei (M4); 23 small lymphocytes (L1) and médium- sized lymphocytes (L2); 24 large lymphocytes (L3);25 thrombocytes: aggregated throm bocytes (T1); 21 thrombocytes: spindle-shaped nuclei (T2) and oval nuclei (T3). Measuring scale $=25 \mu \mathrm{M}$ 


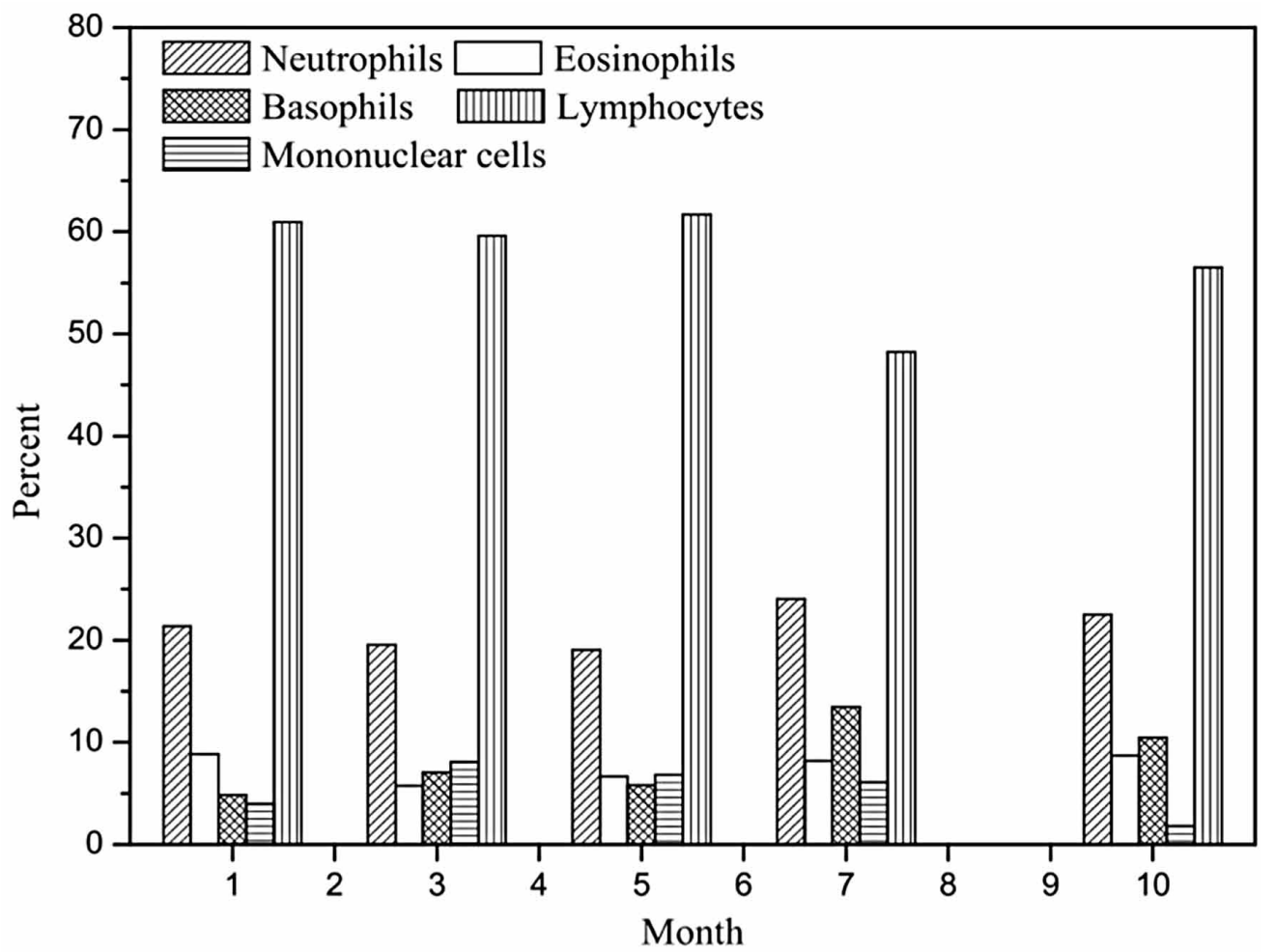

Fig. 2. Morphologucal parameters of WBC of Bufo Bufo gargarizans.

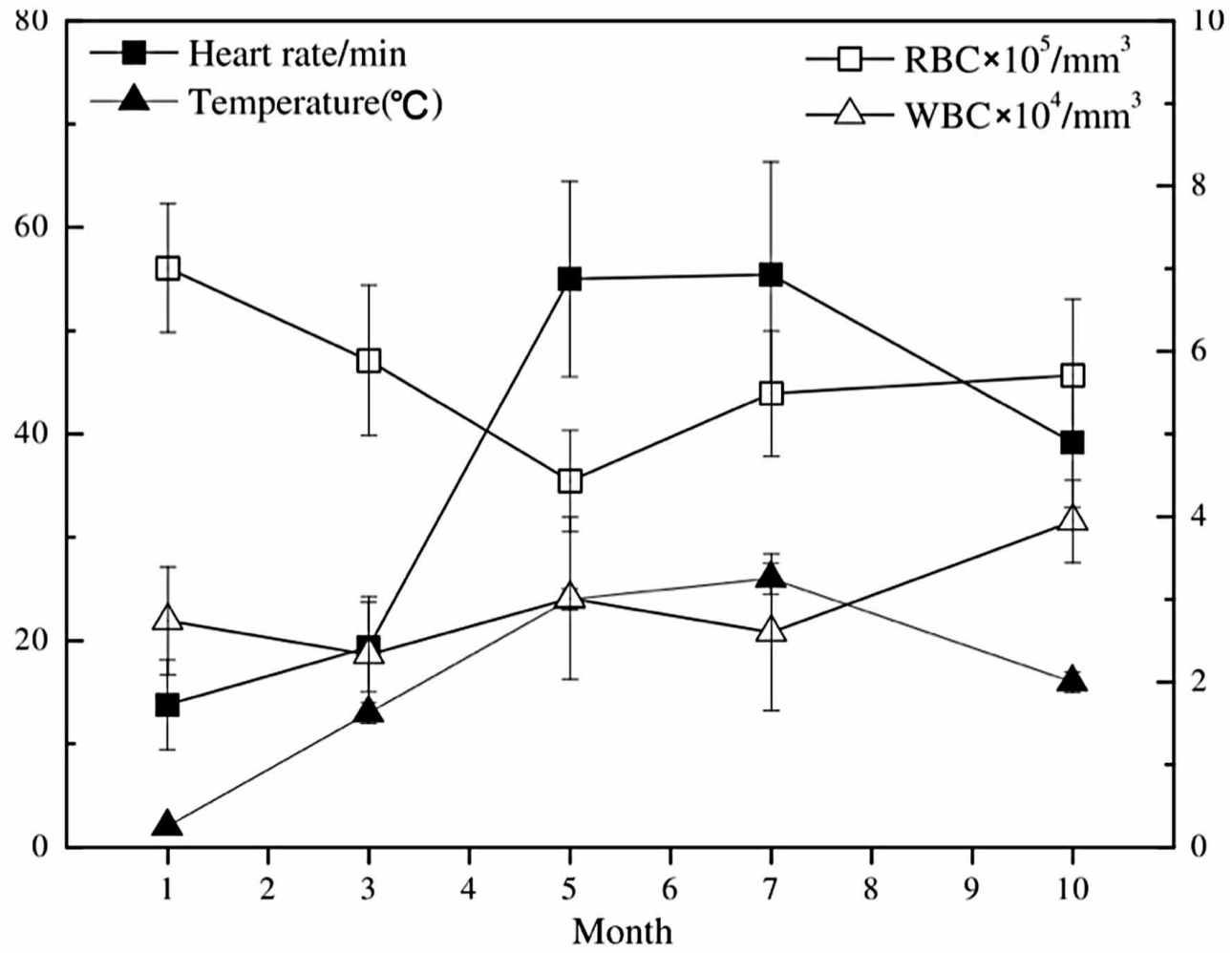

Fig. 3. Annual change of HR, BT, NRBC and NWBC of Bufo Bufo gargarizans. 
Table IV. Annual change of HR, BT, NRBC and NWBC of Bufo Bufo gargarizan.

\begin{tabular}{lccccc} 
& January & March & May & July & October \\
\hline $\mathrm{HR} / \mathrm{min}$ & $13.8 \pm 4.26$ & $19.37 \pm 4.33$ & $55.01 \pm 9.45$ & $55.45 \pm 10.9$ & $39.15 \pm 6.29$ \\
$\mathrm{BT} / \mathrm{oC}$ & $2.0 \pm 0.5$ & $13.0 \pm 1.0$ & $24.0 \pm 1.0$ & $26.0 \pm 1.5$ & $16.0 \pm 1.0$ \\
$\mathrm{NRBC} / \mathrm{x} 105 \mathrm{~mm}^{3}$ & $7.01 \pm 0.78$ & $5.89 \pm 0.91$ & $4.43 \pm 0.61$ & $5.49 \pm 0.76$ & $5.71 \pm 0.92$ \\
$\mathrm{NWBC} / \mathrm{x} 10^{4} \mathrm{~mm}^{3}$ & $2.74 \pm 0.65$ & $2.33 \pm 0.7$ & $3.01 \pm 0.98$ & $2.60 \pm 0.95$ & $3.94 \pm 0.5$ \\
\hline
\end{tabular}

Lymphocytes account for $57.40 \%$ in white cells, and account for $93.05 \%$ in nongranular leukocytes. Lymphocytes include small lymphocytes (SLPC, Fig. 1.23) and large lymphocytes (LLPC, Fig. 1.24). Small lymphocytes are orbicular or suborbicular and nuclei are deflected to one side of cells. Nucleus are stained bluish violet while cytoplasms stained light blue. The morphology of large lymphocytes is similar to that of the small lymphocytes, but nuclear staining is slightly lighter with more abundant cytoplasms. In addition to large and small lymphocytes, there are some mediumsized lymphocytes, the volume of which is between the large and small lymphocytes (Fig. 1.23). The surface of lymphocytes is rough, extending outwards many villous tubercles. Thrombocytes (Table III )

Thrombocytes (Table III). Thrombocytes are similar to the plastocytes of mammals. The cell bodies of thrombocytes are a little small and they are spindle-shaped or oval (Fig. 1.25). The volume of nuclei is relatively large, but cytoplasms generally only have an extremely thin peripheral circle. Thrombocytes are often found in piles in a blood smear (Fig. 1.26), but they may also exist dispersedly. The major diameter of thrombocytes reaches the minimum value in May, and reaches maximum value in March (Table III).

Heart Rate (HR). The heart rate, body temperature (BT), the number of red blood cells (NRBC), and the number of white blood cells (NWBC) of Bufo Bufo gargarizans (Table IV), and monthly changes are shown in Figure 3.

\section{DISCUSSION}

Annual Period Change Rule of Red Blood Cells. From the annual change, the study finds that the ratio of major diameter to minor axis of red blood cells in Bufo Bufo gargarizans is close to the ratio of major diameter to minor axis of the nuclei, but the concentration of red blood cells changes greatly.

In morphology, mature red blood cells in spring and summer are relatively small while those in autumn and winter are relatively large; in January, Bufo Bufo gargarizans are in the medium term of hibernation, hence the average daily body temperatures are $2 \pm 0.5{ }^{\circ} \mathrm{C}$ with the weakest respiration, the slowest blood circulation the lowest heart rate, and maximum number of red blood cells; in May and July, the average daily body temperatures are between $24{ }^{\circ} \mathrm{C}$ $\sim 26{ }^{\circ} \mathrm{C}$, and the corresponding physiological phenomena are opposite to those in January, which indicates red blood cells adapt to the external environment by changing their volumes and number.

In the annual period, mitotic phases in red blood cells can be seen. The proportion of mitotic figures is relatively small in January, March and October, while larger in May and the largest in July, which is consistent with the activity amount of animals. In addition, juvenile red blood cells could also be seen in each month of the annual period, which shows Bufo Bufo gargarizans can not only produce red blood cells by hematopoietic organs when in activity, but also can produce juvenile red blood cells by hematopoietic organs in hibernation, in addition, these juvenile red blood cells can gradually become mature in the circulating blood.

The fact that deformed red blood cells or red blood cells extending pseudopodia appear among part of red blood cells shows that red cells may have phagocytosis, and domestically Wang \& Rao (1996) has already reported that the red blood cells of fish and amphibians possess phagocytosis

\section{Annual Period Change Rule of Granulocytes}

Neutrophils. Neutrophils are involved with inflammatory reaction of organisms, owning active motor ability as well as the function of phagocytizing and digesting bacteria (Cao $\&$ Zhu, 2006). The proportion of neutrophils accounting for in the total number of white blood cells is highest in July, $24.04 \%$, which may be related to the fact that bacteria as well as viruses reproduce vigorously and invade organisms of Bufo Bufo gargarizans in summer.

Basophils. Cytoplasms of basophils are filled with coarse granules, which are related to their strong function of motion defense and phagocytosis ( $\mathrm{Li}$ et al.). In the research, the author has observed more basophils than Guo et al., did, but the shape is relatively small. Basophils reach maximum number in July, which may be related to the fact that the 
activity of Bufo Bufo gargarizans is exuberant and basophils are active.

Annual Period Change Rule of Nongranular Leukocytes. Monocytes are relatively large leucocytes in the blood, and they exist in all vertebrates, playing an important role in nonspecific immunity (Cao et al.) The proportion of monocytes accounting for in leucocytes reaches the highest in March, while the proportion of lymphocytes accounting for in leucocytes reaches the highest in May, which may be related to their entering luxuriant reproductive period.

Annual Period Change Rule of Thrombocytes. Thrombocytes are a kind of cell having protective effect. In addition to the function of hemostasis and blood coagulation, thrombocytes also have the function of deformation, adhesion, aggregation and release (Lu et al., 2008). Thrombocytes distribute in the whole annual period, and accounted for the highest proportion in July by statistic, which may be related to the fact that animal activities are frequent in July with greater probability of wound, and more thrombocytes are needed for wound healing.

Annual Period Change Rule of Heart Rate. The heart rate of Bufo Bufo gargarizans changes according to the changes in body temperature, and they would go into a state of hibernation when their body temperature is below $13^{\circ} \mathrm{C}$. The heart rate of Bufo Bufo gargarizans has a positive correlation with their body temperature in a certain range, and this change becomes more obvious before and after hibernation.

ACKNOWLEDGEMENTS. We would like to express thanks to Guanjun Yang from Henan University of Construction for his contribution in image manipulation.

LIU, C.; XIA, C.; XIE, Z.; JIAO, Y. \& SHE, Q. Investigación de las células sanguíneas periféricas en un periódo anual del Bufo Bufo gargarizans. Int. J. Morphol., 31(4):1282-1288, 2013.

RESUMEN: Se realizó el presente estudio histológico de las células sanguíneas de Bufo Bufo gargarizans en diferentes meses del año: enero, marzo, mayo, julio y octubre. Fueron utilizados métodos de rutina por frotis de sangre con tinción de Wright y observación in vivo. Encontramos dos tipos principales de células de glóbulos rojos al frotis como también en células in vivo: mitóticas y amitóticas. Por cuanto amitosis se produce durante todo el año, sobre todo en el mes de julio, la mitosis hasta el momento se había observado solamente en julio.Además, se encontró una gran cantidad de neutrófilos en los glóbulos de Bufo Bufo gargarizans. Los núcleos de estas células son polimórficos, especialmente en enero y marzo. La concentración de glóbulos rojos era más bajo en mayo y más alta en enero; la concentración de las células blancas de la sangre fue mayor en octubre y menor en marzo. En cuanto a los granulocitos, eosinófilos estos presentaron una mayor proporción en julio y octubre, mientras que los neutrófilos y basófilos registraran una mayor proporción en el mes de julio. Los agranulocitos y las células mononucleares alcanzaron el valor más alto en marzo, y el valor más bajo en enero. Los linfocitos y el valor máximo fue registrado en mayo, el valor más bajo fue registrado en julio. No fueron evidentes los cambios morfológicos de trombocitos, lo que podría tener relación con su estabilidad.

KEY WORDS: Bufo Bufo gargarizans; Céluas sanguínes; Cambios anuales.

\section{REFERENCES}

Cao, F. J. \& Zhu, X. Y. Microstructure of peripheral blood cells in Lutjanus erythopterus. Marine Sci., 30(5):32-5, 2006.

Guo, X. G.; Zhang, Y. X.; Wang, Z. J. \& Zhang, X. F. Study on blood cell of Bufo gargarizans. Sichuan J. Zool., 21(4):211-4, 2002.

Hou, S. W.; Wang, X. L. \& Wang, Z. Y. A histological observation of the blood of Randon sibiricus. Asiat. Herpetol. Res., (45):58-61, 1995.

Li, G. F.; Meng, S. Q.; Li, T. \& Yao, J. X. Peripheral Hematocytes in Caecilian Ichthyophis bannanica. Chinese J. Zool., 44(2):102-7, 2009.

Lu, W. X.; Wang, Y.; Jia, Y. T.; Yue, F.; Zhang, X. Y.; Li, T. S.; Qu, P.; Su, Q. J. \& Li, S. A. Comparison of blood cells of some heterotherm vertebrate species. Acta Zool. Sin.?54(2):387-92, 2008.
Pan, Y. Z. A histological study of the blood of the common Frog, Rana nigromaculata. Acta Sci. Nat. Univ. Pekin., 1:89-101, 1956.

Wang X. D. \& Rao, J. R. The discovery and studies of the extensive erythrocytic phagocytosis. J. Fish. China, 20(1):72-5, 1996.

Zhou, Q. P.; Zhou, X. L. \& Wei, G. B. Observation on the Blood Cells of Bufo Gargarizans of Shuicheng by LM. J. Henan Normal Univ., 39(4):155-8, 2011.

\section{Correspondence to: \\ Dr. Qiusheng She \\ Department of Bioengineering \\ Henan University of Urban Construction \\ Daxiangshan Road \\ Xin Cheng Area \\ Pingdingshan 467036, Henan \\ CHINA}

Received: 03-08-2013

Accepted: 11-02-2013

Email: sheqiusheng828@163.com 